\title{
Penerapan Pembuatan Teknik Lubang Biopori Resapan Sebagai Upaya Pengendali Banjir
}

\author{
Corry Yohana \\ Universitas Negeri Jakarta, Indonesia, corry_yohana@yahoo.com \\ Dientje Griandini \\ Universitas Negeri Jakarta, Indonesia, dientjegriandini@yahoo.com \\ Said Muzambeq \\ saidmuzambiq@ymail.com
}

\begin{abstract}
The students of State University of Jakarta (UNJ) try to apply the bio pore hole technique to restraint the flood problem through the community service program. The purpose of this program is (1) sharing knowledge to campus community about application of science and technology, (2) adding skill to general community especially the college student of UNJ in using bio pore holes technique to avoid the flood problem, (3) Improving the image of UNJ as a supplier of versatile functional technology to the developing regions. The method that have been used for this community service program are lecturing, discussing and direct practicing after material delivery through individual and groups.
\end{abstract}

Keywords: bio pore, flood management

\section{PENDAHULUAN}

\section{Analisis Situasi}

Jakarta, kota yang menawarkan sejuta pesona sehingga banyak orang dari berbagai daerah Indonesia yang mendatanginya. Hal itu membuat infrastruktur pertumbuhan ekonomi dan persoalan terhadap pemenuhan kebutuhan ruang kota yang terusmenerus meningkat, khususnya Available at http://journal.unj.ac.id/unj/index.php/jpm perumahan berjalan pesat selama 20 tahun terakhir. Kebutuhan akan ruang semakin meningkat sebagai akibat meningkatnya aktivitas sosial-ekonomi masyarakat. Sedangkan disisi lain, yaitu luasan ruang yang ada sangat terbatas, semakin langka dan mahal, sehingga mendorong pemanfaatan ruang yang bersifat memaksimalkan kondisi ruang yang ada, akibat perencanaan tata kota 
yang salah membuat Jakarta mempunyai masalah serius setiap tahunnya yaitu Banjir dan kelangkaan air serta penurunan permukaan tanah akibat air tanah yang disedot secara berlebihan. Ketinggian permukaan tanah menurun ditambah curah hujan yang tidak terserap tanah membuat banjir kian parah saja.

Lubang resapan biopori dan sumur resapan menjadi salah satu solusi terbaik karena cocok untuk diterapkan diwilayah Jakarta, dapat dibuat berdampingan dengan berjalannya proyek perluasan ruang terbuka hijau, hanya memerlukan dana sedikit untuk membuatnya, mudah untuk membuatnya, sangat efektif menyerap air dan lubang resapan biopori dapat mengurangi sampah organik yang terbuang ke tempat pembuangan akhir.

Disisi lain, sekarang pemprov Jakarta sedan berusaha melakukan pencegahan banjir dan kelangkaan air dengan menambah luas ruang terbuka hijau. Namun, berdasarkan berita dari Kompas, 2011 "Saat ini Jakarta hanya mempunyai ruang terbuka hijau seluas 9,8 persen". Sedangkan berdasarkan UndangUndang Nomor 26 tentang Tata Ruang disebutkan bahwa idealnya sebuah provinsi memiliki ruang terbuka hijau seluas 30 persen dari total wilayahnya. Namun, untuk menambah ruang terbuka hijau sesuai undang-undang terlihat akan memakan waktu yang lama dikarenakan keterbatasan ruang dan mahalnya harga tanah. Dapat dibayangkan jika DKI Jakarta harus menambah ruang terbuka hijau sesuai undang-undang maka perlu pembebasan lahan hingga 200 kali luas monas. Maka dari itu, selama perluasan ruang terbuka hijau berjalan untuk mengurangi banjir dan kelangkaan air dapat dibarengi dengan cara yang lebih mudah yaitu dengan membuat lubang resapan biopori dan sumur resapan.

Banjir adalah suatu peristiwa yang terjadi akibat menumpuknya air yang jatuh dan tidak dapat di tampung oleh tanah. Peristiwa ini terjadi karena air yang jatuh ke dataran tidak memiliki daerah tangkapan atau dengan kata lain tanah-tanah diperkotaan jenuh air. Untuk itu dalam mengatasi masalah banjir tidak hanya melalui parit-parit drainase, tetapi juga memperbanyak daerah-daerah tangkapan air (water reservoir). Maka masalah banjir dapat diatasi dengan 
membuat lubang resapan biopori yang efektif dan dapat menjadi water reservoir. Selain banjir dapat dimitigasi air tanah juga dapat dilestarikan. Metode yang paling efektif untuk digunakan didaerah urban adalah lubang resapan biopori.

Pembuatan lubang resapan biopori merupakan solusi teknologi ramah lingkungan untuk mengatasi ketersediaan air tanah dengan memanfaatkan sampah organik melalui lubang kecil dalam tanah. Air dan sampah adalah dua hal yang tidak akan lepas dari kehidupan makhluk hidup, termasuk manusia. Setiap manusia setiap hari menghasilkan sampah dari aktifitas hidupnya. Terkadang sampah menjadi sumber masalah pencemaran lingkungan, padahal sampah mempunyai potensi besar dalam menyelamatkan lingkungan, jika diperlakukan secara arif dan bijaksana. Sementara air, sangat penting bagi makhluk hidup. Tanpa air, makhluk hidup akan mati. oleh karena itu, perlu dilakukan pengolahan air dan sampah untuk melangsungkan kehidupan.
Beberapa alasan kenapa lubang resapan biopori menjadi alternatif dalam pengelolaan air dikawasan urban adalah:

1. Daerah yang sempit sehingga tidak memungkinkan untuk pembuatan danau-danau buatan

2. Praktis serta dapat dibuat oleh siapa saja

3. Salah satu cara untuk memperbaiki kondisi tanah dan memperoleh pupuk organik bagi yang gemar bercocok tanam.

4. Metode murah meriah serta dapat menumbuhkan semangat gotong royong di setiap lingkungan daerah urban.

Pembuatan lubang respan biopori dapat dilakukan dimana saja, dengan ketersediaan tanah yang tidak terlalu luas. Teknologi yang dikembangkan oleh Kamir (2006) ini sangat cocok diterapkan di wilayah perkotaan yang tanahnya penuh bangunan sehingga penyerapan air menjadi minim.

Lubang resapan biopori dan sumur resapan menjadi salah satu solusi terbaik karena cocok untuk diterapkan diwilayah Jakarta, dapat dibuat berdampingan dengan berjalannya 
proyek perluasan ruang terbuka hijau, hanya memerlukan dana sedikit untuk membuatnya, mudah untuk membuatnya, sangat efektif menyerap air dan lubang resapan biopori dapat mengurangi sampah organik yang terbuang ke tempat pembuangan akhir. Untuk hal tersebut metode lubang resapan biopori paling tepat dan efisien dipergunakan untuk daerah urban terutama berkaitan dengan pengendalian banjir.

Dengan memanfaatkan lubang kecil dan sampah organik maka wilayah perkotaan yang terlihat kering dan gersang akan berubah menjadi wilayah yang ramah lingkungan. Disamping itu, sampah organik yang tersimpan didalam lubang, dapat dijadikan sebagai sumber penghasil kompos yang dapat digunakan untuk menyuburkan tanaman.

\section{Perumusan Masalah}

Dari uraian di atas dapat dikemukakan permasalahan sebagai berikut:

1. Bagaimana masyarakat kampus dapat merencanakan dan merancang serta membangun wawasan teknik biopori
2 Bagaimana masyarakat kampus UNJ dapat berpartisipasi mengembangkan teknik biopori terhadap masyarakat kota dalam membangun lingkungan berkaitan dengan pengendalian banjir

\section{Tujuan Kegiatan}

Kegiatan ini bertujuan:

1. Memberikan pengetahuan dan wawasan kepada masyarakat kampus dalam penerapan IPTEKS

2. Menambah ketrampilan kepada masyarakat kampus khususnya mahasisiwa FE UNJ dapat menerapkan teknik Lubang Resapan Biopori sebagai alternatif mencegah dampak genangan air dan banjir.

3. Meningkatnya citra UNJ sebagai perguruan tinggi pemasok teknologi tepat guna untuk kawasan daerah berkembang.

\section{Manfaat}

Manfaat kegiatan ini adalah:

1. Memaksimalkan air yang meresap ke dalam tanah sehingga menambah air tanah.

2. Mengurangi genangan air yang menimbulkan penyakit.

3. Mengurangi resiko banjir lokal disekitar areal UNJ. 
3 Mencegah terjadinya erosi tanah dan tanah longsor

\section{KAJIAN TEORITIK}

Biopori adalah lubang lubang yang ditimbulkan oleh makhluk hidup atau mikoorganisme. Metode biopori pertama kali dipopulerkan oleh Kamir seorang professor dari Institut Pertanian Bogor (IPB) Kamir Raziudin Brata. Lubang resapan biopori adalah metode yang diilhami dari dunia pertanian yang akrab dikenal dengan rorak. Lubang rorak digunakan untuk menangkap air yang jatuh di daerah lahan-lahan yang miring untuk meminimalisasi erosi. Lubang resapan biopori dapat juga dijadikan sebagai komposter sederhana untuk memproduksi pupuk organic yang akrab dengan sebutan kompos.

Didaerah perkotaan fungsi utama lubang resapan biopori adalah untuk meminimalisasikan masalah banjir yang kerap menyerang daerah perkotaan apabila musim hujan. Dalam hal ini lubang resapan biopori juga berperan sebagai water reservoir (penangkap air) yang semakin minim dikawasan urban.
Pengambilan air tanah yang tidak diimbangi dengan semangat konservasi, yaitu dengan memasukkan air hujan ke dalam tanah akan berakibat pada berkurangnya ketersediaan air tanah. Apalagi pada daerah yang baru terbangun, dengan mengubah ground cover dari bahan yang tidak ramah pada sumberdaya air, dari sawah/tegalan menjadi permukiman dengan segala bentuk bahan perkerasan halamannya, membuat debit air larian meningkat drastis.

Semangkin terbatasnya air tanah hal ini disebabkan oleh semakin sempitnya lahan terbuka yang berfungsi sebagai peresapan air hujan, banyak lahan produktif beralih fungsi menjadi perumahan, ruko dll. Dengan berkurangnya peresapan maka air hujan langsung mengalir kesungai yang selanjutnya menuju ke laut.

Memperhatikan kondisi tersebut akibat dari pembangunan yang terus dilakukan akan memberikan konsekwensi terjadinya banjir sehingga akan mempengaruhi pola tata ruang hidrologi suatu daerah. Banjir adalah suatu peristiwa yang terjadi akibat 
menumpuknya air yang jatuh dan tidak dapat di tampung oleh tanah. Peristiwa ini terjadi karena air yang jatuh ke dataran tidak memiliki daerah tangkapan atau dengan kata lain tanah-tanah diperkotaan jenuh air. Untuk itu dalam mengatasi masalah banjir tidak hanya memalaui parit-parit drainase, tetapi juga memperbanyak daerah-daerah tangkapan air (water reservoir). Karenaya masalah banjir dapat diatasi dengan membuat lubang resapan biopori yang efektif dan dapat menjadi water reservoir. Selain banjir dapat dimitigasi air tanah juga dapat dilesterikan.

Metode yang paling efektif untuk digunakan didaerah urban adalah lubang resapan biopori. Beberapa alasan kenapa lubang resapan biopori menjadi alternatif dalam pengelolaan air dikawan urban terutama berkaitan dengan pengendalian banjir.

\section{Dasar Teori}

Metode lubang resapan biopori adalah lubang yang dengan diameter 10 sampai $30 \mathrm{~cm}$ dengan panjang 30 sampai $100 \mathrm{~cm}$ yang ditutupi sampah organik yang berfungsi untuk menjebak air yang mengalir di sekitarnya sehingga dapat menjadi sumber cadangan air bagi air bawah tanah, tumbuhan di sekitarnya serta dapat juga membantu pelapukan sampah organik menjadi kompos yang bisa dipakai untuk pupuk tanaman. Biopori adalah pori-pori berukuran kecil (terowongan kecil) yang dibuat oleh aktivitas fauna tanah atau akar tanaman. Lubang tersebut disebut biopori, karena lubang yang dibuat tersebut diisi dengan bahan organik (sampah), kemudian dimasuki cacing dan tidak terjadi pencemaran. Dengan teknologi ini, kita membuat tempat untuk makhluk hidup untuk penyerapan air dengan memanfaatkan apa yang kita buang (sampah). Oleh karena itu, yang paling kita butuhkan dalam penerapan teknologi ini adalah kesadaran untuk tidak membuang sampah, karena sampah adalah sumber daya, terutama sampah organik (http://www.biopori.com)

Menurut penelitian dosen pertanian IPB, Kamir R Brata (2006) lubang resapan biopori dapat mencegah banjir dengan memanfaatkan sampah organik. Air adalah sesuatu yang sangat dibutuhkan dan keberadaannya bisa 
sangat membahayakan ketika terjadi banjir. Sementara sampah adalah sumber daya yang dapat diolah menjadi produk yang bermanfaat, tetapi terkadang sampah menjadi sumber pencemaran bahkan merupakan penyebab banjir jika pembuangannya dilakukan secara sembarangan.

Air merupakan bagian dari makhluk hidup, yang menyerap hampir 50\% dalam tubuhnya. Tanpa air makhluk hidup akan mati. Selain membutuhkan air, makhluk hidup membutuhkan oksigen dan makanan. Tumbuhan/tanaman membutuhkan makanan dan energi yang diserap melalui akar yang ada di tanah. Proses penyerapan ini akan sempurna apabila kandungan air dalam tanah cukup dan tidak berlebihan. Jika air tanah masih utuh, maka kerja makhluk di tanah ini akan mengganti air yang hilang karena penguapan oleh tanaman dan manusia, dan perlahan muncul sumber air baru yang akan dialirkan ke sungai atau danau serta dapat mendorong air asin untuk tidak masuk ke daratan. Hal ini dapat terjadi jika air cukup diserap oleh tanah (Campbell, 2002: 41)

Available at http://journal.unj.ac.id/unj/index.php/jpm
Air menjadi penyebab banjir jika drainase tidak bisa menampung air saat itu. Jika hujan jatuh secara merata bukan disungai tetapi di daratan, resapan dan meresapnya perlahan-lahan dan akan menjadi sumber air baru. Kalau tidak diresapkan, dari manapun air berasal, hutan, kebun maupun pemukiman kalau dibiarkan akan membebani sungai. Apalagi kalau ditambah dengan sampah yang dibuang sembarangan. Hal ini akan menyumbat sungai dan menimbulkan pencemaran baru bagi sumber air. Jika teknologi ini diterapkan, maka dapat mengurangi terjadinya banjir.

Pembuatan lubang biopori merupakan teknologi ramah lingkungan dan murah. Modal utama adalah kemauan dan kesadaran manusia itu sendiri dalam upaya penyelamatan lingkungan hidup dari ketersediaan air dan pencemaran lingkungan akibat sampah. Semua orang dapat memanfaatkan teknologi ini dengan memanfaatkan air hujan, karena curah hujan ada dimana-mana. Air merupakan kebutuhan pokok manusia. Sehingga perlu ditanamkan kesadaran pentingnya ketersediaan air tanah yang merupakan 
sumber penghidupan makhluk hidup, termasuk manusia, tanaman dan binatang.

\section{Peralatan Dan Bahan}

Peralatan

1. Bor tanah 2 (dua) unit Panjang bortebal $2 \mathrm{~mm}$, panjang $1 \mathrm{~m} \varnothing^{1 / 2}$ inci.

2. Cangkul ringan 1 (satu) unit dan kape 2 (dua) unit.

3. Golok 1 (satu) membantu membuat lubang

4. Ember dan gayung masing-masing 1 unit.

5. Bambu berfungsi untuk mengeluarkan tanah dari mata bor ketika membuat biopori, didesain dengan bagian ujung yang lancip.

6. Plengki 2 (dua) unit

7. Pipa PVC (paralon Ø 3") panjang 30 $\mathrm{cm}$ (dua) unit

8. Kertas koran 10 eksamplar

9. Sendok semen 1 (satu) unit

Bahan

1. Semen dan pasir masing-masing $5 \mathrm{~kg}$

2. Penutup berbentuk bulat atau tidak beraturan dengan pilihan warna sesuai selera dan kreasi masingmasing.
3. Air digunakan untuk melunakkan tanah tempat dibuatnya biopori.

4. ampah organik digunakan sebagai bahan pengisinya. Berupa sampahsampah kering, rumput, daun-daunan dari buah mangga, rambutan dan lainlain 1 karung beras kecil.

\section{Teknik Pembuatan Lubang Resapan}

\section{Biopori:}

1. Membuat lubang silindris di tanah dengan diameter $10-30 \mathrm{~cm}$ dan kedalaman 30-100 cm serta jarak antar lubang 50-100 cm.

2. Mulut lubang dapat dikuatkan dengan semen setebal $2 \mathrm{~cm}$ dan lebar 2-3 centimeter serta diberikan pengaman agar tidak ada anak kecil atau orang yang terperosok.

3. Lubang diisi dengan sampah organik seperti daun, sampah dapur, ranting pohon, sampah makanan dapur non kimia, dsb. Sampah dalam lubang akan menyusut sehingga perlu diisi kembali dan di akhir musim kemarau dapat dikuras sebagai pupuk kompos alami.

4. Pupuk kompos yang terbentuk dalam lubang resapan berfungsi menyuburkan tanaman. 
5. Untuk memperkuat dinding lubang tidak longsor, pangkal lubang perlu dibuat penahan dengan membuat adukan semen selebar $2-3 \mathrm{~cm}$ dan setebal $2 \mathrm{~cm}$ di sekeliling lubang.

6. Jumlah lubang resapan biopori ditentukan berdasarkan luas lahan. Setiap $50 \mathrm{~m}^{2}$ luas lahan dibuat 10 lubang. Perhatiakan contoh perhitungan dibawah ini :

- luas lahan 0 - 50m2 dibutuhkan 10 lubang.

- Luas lahan 50 - $100 \quad \mathrm{~m} 2$ dibutuhkan 20 lubang.

- Luas lahan 100 - 150 m2 dibutuhkan 30 lubang.

\section{Lokasi Pembuatan Lubang Biopori}

1. Pilihlah daerah yang tepat untuk membuat lubang biopori, yaitu pada sekeliling pohon, halaman sekolah, kantor, rumah, dan lain-lain.

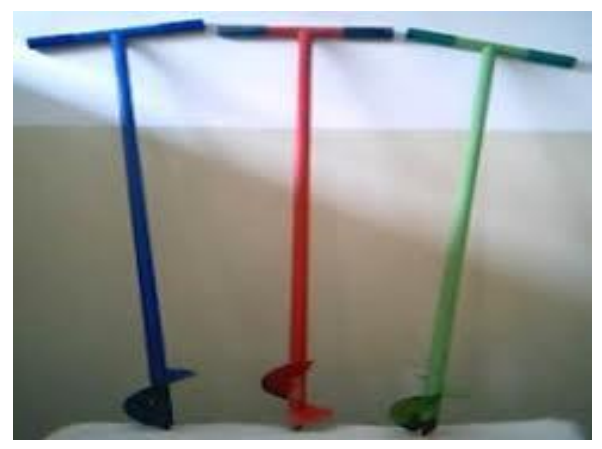

Gambar 1 Bor Tanah

Available at http://journal.unj.ac.id/unj/index.php/jpm
2. Lubangi tanah dengan diameter 10-30 $\mathrm{cm}$ dan kedalaman 80-100 cm menggunakan linggis, bambu, atau alat pengebor biopori (lihat gambar)

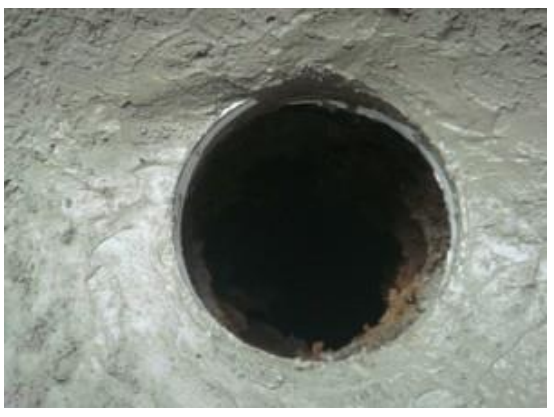

\section{Gambar2.Lubang Tanah}

3. Lubangi tanah dengan diameter 10-30 cm dan kedalaman 80-100 cmmenggunakan linggis, bamboo, atau alat pengebor biopori (lihat gambar).

4. Isilah lubang tersebut dengan sampah dapur, dedaunan, pangkasan tanaman atau rumput, sampah kebun.

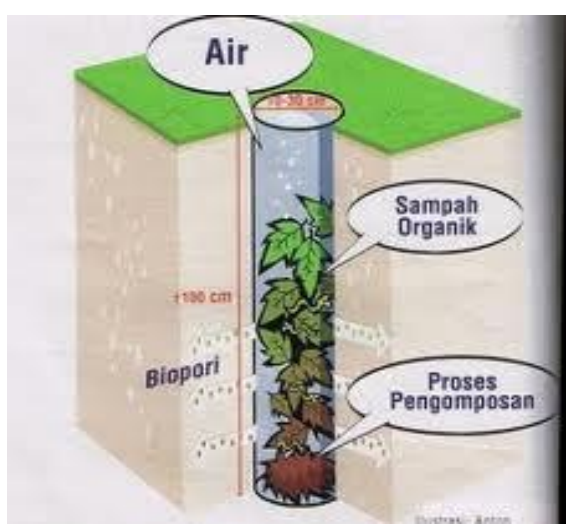

Gambar 3. Lubang Biopori

5. Jika volume sampah berkurang, isilah kembali dengan sampah-sampah seperti yang disebutkan diatas. 
6. Kompos diambil setiap akhir musim kemarau bersamaan dengan pemeliharaan kembali lubang resapan biopori tersebut.

\section{MATERI DAN METODE}

\section{Kerangka Pemecahan Masalah}

Agar masyarakat kampus UNJ dapat berpartisipasi mengembangkan teknik biopori terhadap masyarakat kota dalam membangun lingkungan berkaitan dengan pengendalian banjir, maka diperlukan pelatihan membuat lobang biopori.

\section{RealisasiPemecahanMasalah}

Banjir adalah suatu peristiwa yang terjadi akibat menumpuknya air yang jatuh dan tidak dapat di tampung oleh tanah. Peristiwa ini terjadi karena air yang jatuh ke dataran tidak memiliki daerah tangkapan atau dengan kata lain tanah-tanah diperkotaan jenuh air. Untuk itu dalam mengatasi masalah banjir tidak hanya melalui parit-parit drainase, tetapi juga memperbanyak daerah-daerah tangkapan air (water reservoir). Maka masalah banjir dapat diatasi dengan membuat lubang resapan biopori yang efektif dan dapat menjadi water reservoir. Selain banjir dapat dimitigasi air tanah juga dapat dilestarikan

\section{Khalayak Sasaran}

Dalam acara sosialisasi ini khalayak sasaran adalah masyarakat lingkungan kampus Universitas Negeri Jakarta khususnya mahasisiwa/i berjumlah \pm 45 mahasiswa/i. Agar dapat melaksanakan kegiatan pembuatan lubang biopori untuk menambah wawasan yang berkaitan dengan pengendalian genang air akibat banjir berkaitan dengan pengabdian masyarakat ke bebarapa daerah nantinya.

\section{Metode}

Metode yang akan dilakukan pertama yaitu dengan pemberian dan pembekalan teori-teori yang berkaitan dengan biopori kedua adalah dengan peraktek dan peragaan langsung pembuatan biopori. Dalam kaitan itu sesuai dengan permasalahan dan tujuan tersebut di atas bahwa yang paling efektif untuk digunakan di daerah urban adalah lubang resapan biopori.

\section{HASIL DAN PEMBAHASAN}

Pembuatan lubang resapan biopori, membutuhkan kemampuan dan 
kesadaran yang tinggi terhadap upaya penyelamatan lingkungan dari kurangnya ketersedaiaan air pada musim kemarau dan melimpahnya air hujan disaat musim penghujan. lubang ini diisi oleh sampah organi sisa rumah tangga yang kemudia dibiarkan membusuk dan menjadi tempat berkembangnya mikrobia tanah untuk membuat pori-pori dalam tanah sebagai tempat untuk menjebak air hujan, sehingga proses penyerpan air hujan dalam tanah lebih maksimal.

Pembuatan lubang resapan biopori sangat penting dilaksanakan terutama di daerah yang padat penduduk, dan lokasi tanah penyerapan air sangat minim, sehingga lokasi tersebut sering bermasalah dengan air hujan, seperti genangan air, banjir bahkan munculnya berbagai penyakit yang diakibatkannya, seperti demam berdarah, malaria dan sebagainya. Kelebihan dari lubang resapan biopori adalah minimnya lahan yang digunakan untuk menanam sampah organik, karena hanya membutuhkan tanah seluas 10-30 $\mathrm{cm}^{2}$ dengan kedalaman 50-100 cm. Lubang yang dibuat dapat menampung sampah http://journal.unj.ac.id/unj/index.php/jpm organik dengan volume kurang lebih 30 L tanpa menimbulkan bau busuk karena sempitnya luas permukaan tempat pembusukan sampah bau dan lubang tersebut bisa ditutup untuk mengurangi penyebaran bau.

Dari hasil kegiatan sosialisasi pembuatan lubang resapan biopori di ruang rapat Universitas Negeri Jakarta yang diikuti sebanya \pm 45 orang mahasiswa/i Universitas Negeri Jakarta. Dapat penulis sampaikan bahwa sosisalisasi tersebut memberikan respon yang positip di kalangan peserta mahasiswa/i hal ini terlihat begitu banyaknya mahasiswa/i memberikan pertanyaan berkaitan dengan Lubang Resapan Biopori ( foto-foto pada lampiran ).

Jumlah lubang biopori yang ada sebaiknya dihitung berdasarkan besar kecil hujan, laju resapan air dan wilayah yang tidak meresap air. Sedangkan mengenai jumlahnya, digunakan dengan perhitungan sebagai berikut:

JumlahLubang $=$ intesitashujan (mm/jam) x luasbidangkedap (m2) / lajuperesapan air per lubang (liter/jam) 
Contoh daerah dengan intensitas hujan $50 \mathrm{~mm} / \mathrm{jam}$ (hujan lebat), laju peresapan air perlubang 3 liter/menit (180 liter/jam) pada $100 \mathrm{~m} 2$ bidang kedap perlu dibuat sebanyak (50 x 100): $180=28$ lubang. Diameter $10 \mathrm{~cm}$, dalam $100 \mathrm{~cm} \mathrm{dpt}$ menampung 7,8-liter sampah organik, berarti tiap lubang dapat diisi sampah organik dapur 2-3 hari. Dengan demikian 28 lubang baru dapat dipenuhi sampah organik yang dihasilkan selama 56 - 84 hari, dimana lubang perlu diisi kembali.

\section{KESIMPULAN DAN SARAN}

\section{Kesimpulan}

Pembuatan lubang resapan biopori masih sangat perlu untuk digalakkan di wilayah lingkungan Universitas Negri Jakarta yang mempunyai 24 titik genangan air. Sementara saat ini penyaluran air limpahan hujan masih mengandalkan saluran drainase yang telah ada sebelumnya. Sementara kondisi lapangan hampir semua menggunakan aspal memperkecil ruang peresapan air. Kondisi tersebut sudah jelas masih minimnya penampung air hujan yang semakin meningkat, apalagi http://journal.unj.ac.id/unj/index.php/jpm kegiatan pembangunan terus mangalami perkembangan, sehingga lingkungan Universitas Negeri Jakarta perlu mentargetkan tersedianya lubang resapan biopori pada tahun 2014/2015. Disamping itu pihak rektotrat dan seluruh sivitas akademik Universitas Negeri Jakarta dan seluruh elemen masyarakat sekitar harus mendukung pelaksanaan program biopori tersebut, termasuk perguran tinggi Universitas Negeri Jakarta yang mempunyai tugas diantaranya pengabdian kepada masyarakat.

\section{Saran}

Berdasarkan kesimpulan diatas maka kami menyarankan:

1. Dibentuk tim pengendaliaan lingkungan UNJ untuk pengendalian banjir

2. Tim ini secara teknis membuat program pelaksanaan lobang biopori pada titik-titik tertentu.

3. Anggota tim ini sebaiknya melibatkan seluruh sevitas akademik dan elemen masyarakat kampus. 


\section{DAFTAR PUSTAKA}

Anonim, Yogyakarta menargetkan satu juta lubang biopori pada tahun 2011, Kompas, 23 Maret 2010 Biopori dalam http://www.biopori.com diakses tanggal 1 Maret 2010.

Campbell, NA., Reece, J.B., Mitchell, L.G., 2002, Biologi, Penerbit Erlangga, Jakarta

Kamir R Brata, 2006, Teknologi Biopori, IPB Press, Bogor

Muzambiq, S. 2011. Analisa Jenis tanah terhadap laju resapan air pada lubang resapan biopori, daerah Amplas Kota Medan, Jurnal Ilmu Pengetahuan dan Teknologi Terapan, vol. 6, ISSN 1907-5030 